\title{
Investigation of Metacognition Skill Levels of Secondary School Students who Participate in Sports: The Case of Isparta
}

\section{Spor Yapan Ortaöğretim Öğrencilerinin Biliş Üstü Beceri Düzeylerinin Incelenmesi: Isparta Örneği}

\begin{abstract}
Mahmut Ulukan
Faculty of Sport Sciences, Dumlupınar University

Yunus Şahinler ${ }^{1}$

Faculty of Sport Sciences, Dumlupınar University

Received: January 312021

Accepted: March 31, 2021

Online Published: April 3, 2021

DOI: 10.30655/besad.2021.32

https//doi.org/10.30655/besad.2021.32

\section{Öz}

Bu araştırmada spor yapan ortaöğretim öğrencilerinin üstbilişsel beceri düzeylerinin belirlenmesi ve çeşitli değişkenler yönünden incelenmesi ele alınmıştır. Araştırmada veri toplama aracı olarak Yıldız Akpınar, Tatar ve Ergin (2009) tarafından geliştirilen Biliş Üstü Ölçeğinden yararlanılmıştır. Veri analizinde SPSS istatistik paket programı kullanılmıştır. Buna göre iki kategorili değişkenler için t testi, ikiden fazla kategori için Tek Faktörlü Varyans Analizi (ANOVA) uygulanmıştır. Analiz sonuçlarına göre spor yapan ortaöğretim öğrencilerinin üst-bilişsel becerilerine yönelik algıları ile anne-baba tutum, fiziksel dinçlik düzeyi ve sağlıklı beslenme değişkenleri arasında yapılan karşılaştırmada anlamlı farklılı olduğu tespit edilmiştir. Ancak spor yapan ortaöğretim öğrencilerin üstbilişsel becerilerine yönelik algıları ile yaş, cinsiyet, sınıf ve psikolojik dinçlik düzey değişkenleri arasında yapılan karşılaştırmada anlamlı farklılık olmadığı görülmüştür.
\end{abstract}

Anahtar Kelimeler: Düşünme, davranış, bilgi

\begin{abstract}
In this study, determining the metacognitive skill levels of secondary school students who participated in sports and examining them in terms of various variables are discussed. As a data collection tool, the Metacognition Scale developed by Yildız Akpınar, Tatar and Ergin (2009) was used in the research. SPSS statistical package program was used in data analysis. Accordingly, t-test for two-category variables and Single Factor Analysis of Variance (ANOVA) for more than two categories were applied. According to the analysis results, a significant difference was found in the comparison between the perceptions of secondary school students engaged in sports towards their meta-cognitive
\end{abstract}

${ }^{1}$ Corresponding Author: Yunus Şahinler yunusahinler@gmail.com

Dumlupınar Üniversitesi, Spor Bilimleri Fakültesi, Kütahya, Turkey 
skills and the variables of parental attitude, physical vigor and healthy nutrition. However, it was observed that there was no significant difference in the comparison between the perceptions of secondary school students engaged in sports towards their metacognitive skills and the variables of age, gender, class and psychological vigor.

Keywords: Thinking, behavior, knowledge

\section{Giriş}

Günümüz bilgi toplumunda her geçen gün yeni bilgiler ortaya çımakta ve teknolojinin de gelişmesiyle birlikte bu yeni bilgiler hızla yayılmaktadır. Bunun sonucu olarak da doğru ve kaliteli bilgiye ulaşmak sürekli olarak zorlaşmaktadır. Çağımızda doğru bilgiye ulaşmak; bilgiyi kullanma ve üretme becerilerine bağlı bulunmaktadır (Çınar, Teyfur \& Teyfur, 2006). Bu becerileri kazanmak ve yaşamı boyunca sürdürmek, bilgi üretimine dayalı modern bir eğitimi gerektirir. Ayrıca doğru ve nitelikli bilgiye ulaşmanın zorluğu da göz önüne alındığında, okulların öğrencilere bilgi aktaran kurumlar olmaktan çıkması; öğrenciye hangi bilgilere nasıl erişeceğini, o bilgiyi nasıl öğreneceğini ve o bilgiyi öğrenmenin gerekli olup olmadığının yargılamasını yapmayı öğretecek, yani öğrenmeyi öğretecek kurumlara dönüştürülmelidir (Baltacı, 2009; Doğan, 2009; Erdamar-Koç, 2007).

Spor ise sağlıklı bir neslin gelişimi ve yetiştirilmesi için temel eğitim aracıdır. Bireylerin refahı ve mutluluğu bir şekilde tam ve sürekli fiziksel ve ruhsal sağlıklarına bağlıdır. Spor, insanların sağlıklı yaşamasında, bireylerin sosyal yaşamında, fiziksel ve zihinsel gelişiminde büyük bir yere sahiptir (Şahan vd., 2008; Yetim, 2000). Çeşitli spor aktivitelerini öğrenmek ve kavramak zihinsel gelişim ve eğitimin amacı ile yakından ilgilidir. Bu amaç bilgi ve anlayışla ilgilidir. Bilgi ve anlayış zihinsel gücün parçalarını oluşturur (Selçuk, 1997).

Üst biliş kavramının ortaya çıkması ve bu konuda yapıımış olan çalışmalarla daha anlamlı bir biçimde hızla ilerlemeye başlamıştır. Biliş, etrafımızdaki dünyayı öğrenmemizi ve anlamamızı sağlayan zihinsel etkinliklerdir (Aydın, 1999). Üstbiliş ise insanın algılama, hatırlama ve düşünme ile ilgili zihinsel aktivitelerin farkına varması ve bilişi kontrol edip düzenleyen ve değerlendiren üst düzeydeki bilişsel yapı, bilgi ve süreçler şeklinde tanımlanmaktadır (Desoete \& Özsoy, 2009; Huitt, 1997; Hacker \& Dunlosky, 2003; Tosun \& Irak, 2008;). Üstbiliş becerileri ileri seviyedeki öğrenciler, bildikleri ve bilmediklerinin farkına vardıklarında üstbilişsel farkındalık ve yeteneklerinin kullanılması öğrencilerin başarılarında yüksek bir etki sağlayacaktır (Doğan, 2013). Hafıza, zekâ ve çevresel faktörler ile ilgili arttırılabilen üstbiliş, öğrenme sürecinde bulunan bilişsel süreçlerle ilgili farklılk yaratan, söz konusu sürecin kullanımını içeren mental bir yetenektir (Baltacı \& Akpınar, 2011). Üstbilişin dış etkenler aracılığıyla geliştirilebilen bir yetenek olduğu gerçeği, öğrenme ve öğretme süreçlerinde değerlendirilmiştir (Esmer \& Yorulmaz, 2017).

Üst biliş terimi, insanın kendi bilişsel süreçlerinin farkında olup tanımasını, izlemesini, kontrol altında tutmasını ve tüm süreçleri değerlendirmesini sağlayan işlemleri ifade etmek ve genel itibariyle bilişe yönelik üst düzey bilişsel yapı ve süreçler olarak tanımlanmaktadır (Brown, 1987; Flavell, 1987; Metcalfe \& Shimamura, 1996; Nelson \& Narens, 1996). Bir başka ifadeyle üstbiliş, insanın zihnindeki gelişen olayların ve işlevlerin farkında olmayı ve zihinsel olayları ve işlevleri amaçlı şekilde yönlendirmeyi kapsayan bir kavramdır (Crick 2000; Dienes \& Perner 1999). Normal bilişin üstünlüğü, farkındalık ya da yetenek düzeyi şeklinde tanımlanan üstbiliş; bilinçli bilme ve düşünme şekli olarak da tanımlanabilir (Baltacı ve Akpınar, 2011). Bu tanımlara ek olarak alan yazındaki birçok araştırmacıya göre üst biliş iki ana olgudan oluşmaktadır (Brown, 1987; Gama, 2004; Schraw, 1998; Yıldız \& Ergin, 2007); bilişsel bilgi ve bilişsel düzenleme yeteneğidir. Bilişsel bilgi, "bilişsel süreci kontrol etme bilgisi" ile ilişkilidir (Bağçeci, Döş, \& Sarıca, 2011). Pintrich, Smith, Garcia ve McKeachie (1991) üstbilişi, bireyin okuduğu ve çalıştığı şeye yönelik hangi sıklıkla düşündüğüne değer vermesi gerektiğini açıkça ortaya 
koymaktadır. Martinez'e (2006) göre ise, kişinin kendi düşüncelerini izlemesi ve kontrol etmesi olan üstbiliş; meta-bellek ya da meta-kavram, problem çözme ve eleştirel düşünme olarak üç temel kategoride ifade etmektedir. Bir başka tanımda ise üstbiliş; bireyin kendi düşünme süreçlerini yönetip kontrol etmesi ve düşüncelerinin farkına varması şeklinde ifade edilmektedir (Kuhn ve Dean, 2004; Özsoy, 2008). Pressley ve Harris (2012) üstbilişi, "bilişsel stratejileri ortayakoyan bilişsel bilgi" olarak tanımlamışlardır. Bir başka tanımda ise üstbiliş, "bilişe yönelik bilgi sahibi olma ve düşünme" olarak tanımlanmıştır (Dean \& Kuhn, 2003; McCormick, 2003; Özkaya, 2017). Özbay ve Bahar (2012) ise üstbilişi; kişinin kendini tanıyıp nasıl öğrendiğini fark etmesi ve böylelikle öğrenme şeklini düzenlemesi şeklinde ifade ettiğini belirtip; üstbiliş stratejilerini kullanmanın öncelikli şartının, bireyin kendini tanıması olduğunu belirtmektedir. Saban (2009) ise üstbilişi; bireyin neyi bildiğini ya da neyi bilmediğini bilmesidir.

Yapılmış olan araştırmalar incelendiğinde; üstbilişin yaş ile beraber artığı ve farklı unsurlarının farklı gelişimsel zaman dilimlerine ait olduğu görülmektedir (Hanten vd., 2004).Bireylerin üstbilişsel farkındalıklarının cinsiyete ve eğitim gördükleri sınıfa bağlı olarak farklılaştığı görülmüştür (Oğuz \& Kutlu-Kalender, 2018). Ancak bazı araştırmalarda bireylerin üstbilişsel farkındalıklarının cinsiyet ve sınıf düzeylerine göre farklılaşma oluşturmadığı yönündedir. (Akbabaoğlu \& Budan, 2020). Üstbilişe yönelik çalışmalarda genel olarak; akademik başarı ve zeka üzerine odaklanıldığı görülmüştür. Spor yapan ortaokul öğrencilerinin üstbiliş farkındalık düzeyleri yaptıkları spor branşlarına ve cinsiyete göre farklılaşmadığı görülmüştür (Tuzcuoğlu \& Özcan, 2014). Beden eğitimi ve spor yüksekokulu öğrencilerinin üst bilişsel farkındalık düzeylerinin ise cinsiyet ve bölümlere göre anlamlı düzeyde farklıık olduğu belirlenmiştir (Kiremitçi, 2013; Yalız-Solmaz, 2015). Yalız-Solmaz (2015) beden eğitimi ve spor yüksekokulu öğrencileri üzerinde yaptığı araştırmada öğrencilerin üst bilişsel farkındalık düzeylerinin cinsiyet ve sınıf düzeylerine göre farklılaşmadığı sonucuna ulaşmıştır.

Sporun biliş üzerindeki olumlu etkisini ortaya koyması açısından spor yapan ortaöğretim öğrencilerinin üst biliş düzeylerinin belirlenerek incelenmesi gerektiği düşünülmektedir. Ayrıca spor alanında yapılan üst-biliş çalışmalarının çoğunun üniversite düzeyi bireyler üzerinde olduğu görülmüştür. Ortaöğretim düzeyinde spor yapan bireyler üzerinde yeterli sayıda üst-bilişsel çalışmaya rastlanmaması, çalışmanın bu alanda literatüre katkı sağlaması açısından önem arz etmektedir. Bu araştırmada spor yapan ortaöğretim öğrencilerinin üstbilişsel beceri düzeylerinin belirlenmesi ve çeşitli değişkenler yönünden incelenmesi amaçlanmıştır.Araştırmada şu problemlere cevap aranmaktadır:

1. Spor yapan ortaöğretim öğrencilerinin bilişüstü becerileri hangi seviyededir?

2. Cinsiyet değişkenine göre spor yapan ortaöğretim öğrencilerinin bilişüstü becerileri arasında anlamlı bir farklılık var mıdır?

3. Yaş değişkenine göre spor yapan ortaöğretim öğrencilerinin bilişüstü becerileri arasında anlamlı bir farklılık var mıdır?

4. Spor türü değişkenine göre spor yapan ortaöğretim öğrencilerinin bilişüstü becerileri arasında anlamlı bir farklılık var mıdır?

5. Sağlıklı beslenme değişkenine göre spor yapan ortaöğretim öğrencilerinin bilişüstü becerileri arasında anlamlı bir farklılık var mıdır?

6. Anne ve baba tutum değişkenine göre spor yapan ortaöğretim öğrencilerinin bilişüstü becerileri arasında anlamlı bir farklıık var mıdır?

7. Fiziksel ve psikolojik dinçlik düzeyi değişkenine göre spor yapan ortaöğretim öğrencilerinin bilişüstü becerileri arasında anlamlı bir farklıık var mıdır? 


\section{Yöntem}

Araştırmada spor yapan ortaöğretim öğrencilerinin üstbiliş düzeylerinin farklı değişkenler yönünden incelenmesi amaçlanmıştır. Araştırma betimsel tarama modelinden faydalanılarak yapılmıştır. Betimsel tarama modeli,bir örneklemdeki kişilerin verilerinin bir ya da daha fazla değişkene göre ne şekilde dağıldığını belirlemek amacıyla kullanılan araştırma yaklaşımıdır. Söz konusu modelde,bütün popülasyondan veri toplamak yerine, evrenin belirli bir kısmından veri toplanabilmektedir (Büyüköztürk vd., 2012; Karasar, 2012).

\section{Evren ve Örneklem}

Araştırmanın evrenini, Isparta'da farklı branşlarda takım ve bireysel sporla ilgilenen ortaöğretim öğrencileri oluşturmaktadır. Araştırmanın örneklemini ise Isparta'da takım ve bireysel branşlarda en az 3 yıl spor yapmıs 259 öğrenci oluşturmaktadır (Büyüköztürk vd., 2012). Araştırmanın örneklemine ilişkin bilgiler Tablo 1'de verilmiştir.

Tablo 1. Katıımcıların Demografik Özellikleri

\begin{tabular}{|c|c|c|c|}
\hline Değişkenler & & $\mathbf{N}$ & $\%$ \\
\hline \multirow{2}{*}{ Cinsiyet } & Kadın & 150 & 57.90 \\
\hline & Erkek & 109 & 42.10 \\
\hline \multirow{3}{*}{ Yaş } & 12 & 79 & 30.50 \\
\hline & 13 & 66 & 25.50 \\
\hline & 14 & 114 & 44.00 \\
\hline \multirow{3}{*}{ Sinıf } & 6. sınıf & 106 & 44.50 \\
\hline & 7. sinıf & 51 & 20.50 \\
\hline & 8. sinıf & 102 & 35.00 \\
\hline \multirow{2}{*}{ Spor Türü } & Takım Sporları & 198 & 76.40 \\
\hline & Bireysel Sporlar & 61 & 23.60 \\
\hline \multirow{3}{*}{ Sağlıklı Beslenme Durumu } & Evet & 121 & 46.70 \\
\hline & Hayır & 52 & 20.10 \\
\hline & Kismen & 86 & 33.20 \\
\hline \multirow{5}{*}{ Anne-Tutum } & Aşırı Serbest & 21 & 8.10 \\
\hline & Normal & 145 & 56.00 \\
\hline & Aşırı Koruyucu & 58 & 22.40 \\
\hline & Otoriter & 24 & 9.30 \\
\hline & İlgisiz & 11 & 4.20 \\
\hline \multirow{5}{*}{ Baba-Tutum } & Aşırı Serbest & 18 & 6.90 \\
\hline & Normal & 134 & 51.70 \\
\hline & Aşırı Koruyucu & 68 & 26.30 \\
\hline & Otoriter & 27 & 10.40 \\
\hline & İlgisiz & 12 & 4.60 \\
\hline \multirow{5}{*}{ Fiziksel Dinçlik Düzeyi } & Çok lyi & 76 & 22.40 \\
\hline & İyi & 89 & 36.70 \\
\hline & Orta & 70 & 25.50 \\
\hline & Zayıf & 11 & 6.20 \\
\hline & Çok Zayıf & 13 & 9.30 \\
\hline \multirow{5}{*}{ Psikolojik Dinçlik Düzeyi } & Çok Iyi & 58 & 23.00 \\
\hline & İyi & 95 & 35.50 \\
\hline & Orta & 66 & 27.50 \\
\hline & Zayıf & 16 & 6.00 \\
\hline & Çok Zayıf & 24 & 8.00 \\
\hline
\end{tabular}




\section{Veri Toplama Araçları}

Araştırmada veri toplama aracı Bilişüstü Ölçeği ve araştırmacılar tarafından hazırlanan Kişisel Bilgiler Formu olarak iki bölümden oluşmaktadır.

\section{Kişisel Bilgiler Formu}

Kişisel bilgiler formunda katıımcıların yaş, cinsiyet, sınıf, spor branşı, sağlıklı beslenme durumu, anne-baba tutumu, fiziksel ve psikolojik dinçlik düzey durumları hakkındaki bilgilere ulaşımasını sağlayacak sorular bulunmaktadır.

\section{Biliş Üstü Ölçeği}

Ölçek Yıldız, Akpınar, Tatar ve Ergin (2009) tarafından geliştirilmiştir. Literatürde daha önce yapılmış olan çalışmalar araştırmacılar tarafından incelenmiş ve üstbilişi, bilişin bilgisi ve bilişin düzenlenmesi olarak iki temel başlık altında incelemeyi daha uygun görmüşlerdir. Bilişin bilgisi başlığı altında;"açıklayıcı bilgi", "yöntemsel bilgi" ve "koşulsal bilgi"; bilişin düzenlenmesi başlığı altında ise;"planlama", "bilişsel strateji", "kendini izleme", "kendini kontrol etme" ve "kendini değerlendirme" olarak belirlenmiştir. 30 maddeden oluşan bu ölçek "Her zaman (4)" - "Hiç (1)" olarak 4'lü likert tipinde derecelendirilmiştir. Ölçekten alınabilecek en düşük puan 30, en yüksek puan ise 120'dir. Ölçekten alınan puanlar arttıkça bilişüstü farkındalık ve beceri düzeyleri atmaktadır. Ölçeğin alt boyutlarına ilişkin alınan en düşük ve en yüksek puanlar madde sayılarına göre belirlenmiştir. Bilişin bilgisi için en düşük 17, en yüksek 68; bilişin düzenlenmesi için en düşük 13, en yüksek 52'dir .Ölçeğin Cronbach Alpha iç tutarlılık katsayısı 0.96 olarak hesaplanmıştır. Bu çalışma için Cronbach Alpha iç tutarlık katsayısı ise 0.90 olarak hesaplanmıştır.

\section{Veri Toplama Süreci}

Araştırma verilerinin toplanması için araştırmacılar tarafından Isparta'da çeşitli okullarda okuyan öğrencilere ilgili oldukları spor alanlarında, okullarda ve spor tesislerinde ölçekler doldurulmuştur. Ölçeğin doldurulma süresi 10-15 dk arasındadır. Öğrenciler tarafından doldurulan ölçeklerin 278'i geri dönüş yapmış olup 19'u araştırma şartlarını sağlamadığından (eksik doldurulduğu ya da soruların cevaplanmadığı tespit edildiğinden araştırma dışı tutulmuştur. Dolayısıyla araştırma 259 öğrenciden toplanan veriler ile analiz edilmiştir.

\section{Veri Analizi}

Çalışma kapsamındaki araştırmada toplanan veriler SPSS 25.0 istatistik paket programı kullanılarak analiz edilmiştir. Demografik faktörlerin belirlenebilmesi için frekans ve yüzde analizlerinden yararlanılmıştır. Değişkenlerin normal dağılımı çarpıklık ve basıklık $(₫ 1,96)$ değerleri ile kontrol edilmiş ve sonuç olarak; parametrik testler olan t-testi ve ANOVA testi kullanılmıştır. Verilerin homojen olup olmama durumu kontrol edilmiş ve neticesinde Benforenni ve tamhane testleri kullanılmıştır. Spor yapan bireylerin üstbiliş seviyelerini belirlemek amacıyla tanımlayıcı istatistikten faydalanılmıştır. Sonuçlar .05 anlamlılık düzeyine göre yorumlanmıştır. 


\section{Bulgular}

Tablo 2 ' de spor yapan öğrencilerin bilişin bilgisi alt boyutundan aldıkları ortalama puan $(\bar{X}=45.67$, Ss= 9.88) olduğu görülmüştür. Öğrencilerin bilişin düzenlemesi alt boyutundan aldıkları ortalama puan $(\bar{X}$ =34.87. Ss= 8.17) olduğu görülmüştür. Spor yapan öğrencilerin tüm ölçekten aldıkları ortalama puan ise $(\bar{X}=80.54$, Ss= 17.26) olarak hesaplanmıştır.

Tablo 2. Spor Yapan Ortaöğretim Öğrencilerinin Üst Bilişsel Beceri Düzeyleri

\begin{tabular}{lccc}
\hline & N & $\mathbf{X}^{-}$ & Ss \\
\hline Bilişin Bilgisi & 259 & 45.67 & 9.88 \\
Bilişin Düzenlenmesi & 259 & 34.87 & 8.17 \\
Ölçeğin Toplamı & 259 & 80.54 & 17.26 \\
\hline
\end{tabular}

Tablo 3 incelendiğinde, cinsiyet değişkenine göre öğrencilerin bilişüstü becerileri arasında anlamlı bir fark yoktur ( $p$ >.05). Ancak ortalama puanlar incelendiğinde kadınların biliş üstü beceri düzeylerinin az farkla erkeklerden yüksek olduğu görülmüştür.

Tablo 3. Spor Yapan Ortaöğretim Öğrencilerinin Cinsiyet Değişkenine Göre Analizi

\begin{tabular}{|c|c|c|c|c|c|c|}
\hline & Cinsiyet & $\mathbf{N}$ & $x^{-}$ & Ss & $\mathbf{t}$ & $\mathbf{P}$ \\
\hline Bilişin Bilgisi & $\begin{array}{l}\text { Kadın } \\
\text { Erkek }\end{array}$ & $\begin{array}{l}150 \\
109\end{array}$ & $\begin{array}{l}46.51 \\
44.51\end{array}$ & $\begin{array}{l}9.75 \\
9.98\end{array}$ & 1.61 & .11 \\
\hline Bilişin Düzenlenmesi & $\begin{array}{l}\text { Kadın } \\
\text { Erkek }\end{array}$ & $\begin{array}{l}150 \\
109\end{array}$ & $\begin{array}{l}35.27 \\
34.33\end{array}$ & $\begin{array}{l}7.50 \\
9.01\end{array}$ & .92 & .36 \\
\hline Ölçeğin Toplamı & $\begin{array}{l}\text { Kadın } \\
\text { Erkek }\end{array}$ & $\begin{array}{l}150 \\
109 \\
\end{array}$ & $\begin{array}{l}81.78 \\
78.84 \\
\end{array}$ & $\begin{array}{l}16.49 \\
18.21 \\
\end{array}$ & 1.35 & .18 \\
\hline
\end{tabular}

Tablo 4 incelendiğinde yaş değişkenine göre öğrencilerin bilişüstü becerileri arasında anlamlı bir fark yoktur ( $p$ >05). Ancak ortalama puanlar incelendiğinde bilişin bilgisi alt boyutunda 12 yaşındaki öğrencilerde, bilişin düzenlenmesi alt boyutunda ise 13 yaşındaki öğrencilerde yüksek olduğu görülmüştür.

Tablo 4. Spor Yapan Ortaöğretim Öğrencilerinin Yaş Değişkenine Göre Analizi

\begin{tabular}{lcccccc}
\hline & Yaş & $\mathbf{N}$ & $\mathbf{X}^{-}$ & Ss & $\mathbf{F}$ & $\mathbf{P}$ \\
\hline \multirow{3}{*}{ Bilişin Bilgisi } & 12 & 79 & 46.25 & 10.63 & & \\
& 13 & 66 & 44.92 & 10.96 & .32 & .72 \\
\hline \multirow{3}{*}{ Bilişin Düzenlenmesi } & 14 & 114 & 45.70 & 8.67 & & \\
& 12 & 79 & 34.08 & 8.94 & & \\
& 13 & 66 & 35.42 & 9.82 & .56 & .57 \\
Ölçeğin Toplamı & 14 & 114 & 35.10 & 6.38 & & \\
& 12 & 79 & 80.34 & 19.03 & & .98 \\
\hline
\end{tabular}


Tablo 5 incelendiğinde, sınıf değişkenine göre öğrencilerin bilişüstü becerileri arasında anlamlı bir fark yoktur ( $p>05$ ). Ancak ortalama puanlar incelendiğinde biliş üstü beceri düzeylerinin 7. sınıfta öğrenim gören öğrencilerde yüksek olduğu görülmüştür.

Tablo 5. Spor Yapan Ortaöğretim Öğrencilerinin Sınıf Değişkenine Göre Analizi

\begin{tabular}{lcccccc}
\hline & Sınıf & $\mathbf{N}$ & $\mathbf{X}^{-}$ & Ss & $\mathbf{F}$ & $\mathbf{P}$ \\
\hline \multirow{3}{*}{ Bilişin Bilgisi } & 6. Sınıf & 106 & 45.72 & 11.08 & & \\
& 7. sınıf & 51 & 46.58 & 10.20 & .36 & .70 \\
& 8. sınıf & 102 & 45.15 & 8.34 & & \\
\hline \multirow{2}{*}{ Bilişin Düzenlenmesi } & 6. sınıf & 106 & 34.20 & 9.33 & & \\
& 7. sınıf & 51 & 36.45 & 8.43 & 1.31 & .27 \\
& 8. sınıf & 102 & 34.78 & 6.54 & & \\
\hline \multirow{2}{*}{ Ölçeğin Toplamı } & 6. sınıf & 106 & 79.93 & 19.86 & & \\
& 7. sınıf & 51 & 83.03 & 17.90 & .66 & .52 \\
\hline
\end{tabular}

Tablo 6 incelendiğinde, spor türü değişkenine göre öğrencilerin bilişüstü becerileri arasında anlamlı bir fark yoktur ( $p>$.05). Ancak ortalama puanlara göre ölçeğin genelinde ve bilişin bilgisi alt boyutunda bireysel spor yapan katılımcıların üst bilişsel beceri düzeylerinin takım sporu yapan katılımcılardan yüksek olduğu görülmüştür. Bilişin düzenlenmesi alt boyutunda ise takım sporu yapan katılımcıların biliş üstü beceri düzeylerinin bireysel spor yapanlardan yüksek olduğu görülmüştür.

Tablo 6. Spor Yapan Ortaöğretim Öğrencilerinin Spor Türü Değişkenine Göre Analizi

\begin{tabular}{|c|c|c|c|c|c|c|}
\hline & Spor Türü & $\mathbf{N}$ & $\mathrm{X}^{-}$ & Ss & $\mathbf{t}$ & $\mathbf{P}$ \\
\hline \multirow{2}{*}{ Bilişin Bilgisi } & Takım Sporları & 198 & 45.47 & 10.25 & \multirow{2}{*}{-.58} & \multirow{2}{*}{.56} \\
\hline & Bireysel Spor & 61 & 46.31 & 8.62 & & \\
\hline \multirow{2}{*}{ Bilişin Düzenlenmesi } & Takım Sporları & 198 & 35.04 & 8.33 & \multirow{2}{*}{.58} & \multirow{2}{*}{.56} \\
\hline & Bireysel Spor & 61 & 34.34 & 7.66 & & \\
\hline \multirow{2}{*}{ Ölçeğin Toplamı } & Takım Sporları & 198 & 80.51 & 17.77 & \multirow{2}{*}{.- .06} & \multirow{2}{*}{.96} \\
\hline & Bireysel Spor & 61 & 80.65 & 15.62 & & \\
\hline
\end{tabular}

Tablo 7 incelendiğinde, anne-tutum değişkenine göre öğrencilerin bilişin bilgisi alt boyutuna ilişkin algıları arasında anlamlı farklıık olduğu belirlenmiştir ( $F=4.31, p<.05)$. Bu farklıı̆ın yönünün (aşırı serbest < otoriter) ve (ilgisiz<otoriter) arasında olduğu görülmüştür. Anne-tutum değişkenine göre öğrencilerin bilişin düzenlenmesi alt boyutuna ilişkin algıları arasında anlamlı farklılı bulunmuştur $(F=3.47, p<.05)$. Bu farklıığın yönünün (aşırı serbest<aşırı koruyucu) ve (aşırı serbest<otoriter) arasında olduğu görülmüştür. Anne tutum değişkenine göre öğrencilerin bilişüstü becerileri arasında anlamlı fark olduğu saptanmıştır. Bu farklılığın yönünün (aşırı serbest<aşırı koruyucu) ve (aşırı serbest<otoriter) arasında olduğu görülmüştür. 
Tablo 7. Spor Yapan Ortaöğretim Öğrencilerinin Anne-Tutum Değişkenine Göre Analizi

\begin{tabular}{|c|c|c|c|c|c|c|c|}
\hline & Anne-Tutum & $\mathbf{N}$ & $\mathrm{X}^{-}$ & Ss & $\mathbf{F}$ & $\mathbf{P}$ & $\begin{array}{c}\text { Anlamlı } \\
\text { Fark }\end{array}$ \\
\hline \multirow{5}{*}{ Bilişin Bilgisi } & Aşırı Serbest (a) & 21 & 40.00 & 8.89 & \multirow{5}{*}{4.31} & \multirow{5}{*}{.00} & \multirow{5}{*}{$\begin{array}{l}a<d \\
e<d\end{array}$} \\
\hline & Normal (b) & 145 & 46.07 & 9.17 & & & \\
\hline & Aşırı Koruyucu (c) & 58 & 46.55 & 10.28 & & & \\
\hline & Otoriter (d) & 24 & 49.29 & 12.10 & & & \\
\hline & İlgisiz (e) & 11 & 38.63 & 6.93 & & & \\
\hline \multirow{5}{*}{$\begin{array}{l}\text { Bilişin } \\
\text { Düzenlenmesi }\end{array}$} & Aşırı Serbest (a) & 21 & 30.09 & 7.99 & \multirow{5}{*}{3.47} & \multirow{5}{*}{.01} & \multirow{5}{*}{$\begin{array}{l}a<c \\
a<d\end{array}$} \\
\hline & Normal (b) & 145 & 34.68 & 8.27 & & & \\
\hline & Aşırı Koruyucu (c) & 58 & 36.12 & 8.40 & & & \\
\hline & Otoriter (d) & 24 & 38.20 & 6.49 & & & \\
\hline & İlgisiz (e) & 11 & 32.72 & 4.31 & & & \\
\hline \multirow{5}{*}{ Ölçeğin Toplamı } & Aşırı Serbest (a) & 21 & 70.09 & 16.43 & & & \multirow{5}{*}{$\begin{array}{l}a<c \\
a<d\end{array}$} \\
\hline & Normal (b) & 145 & 80.75 & 16.68 & & & \\
\hline & Aşırı Koruyucu (c) & 58 & 82.67 & 17.85 & 4.09 & .00 & \\
\hline & Otoriter $(\mathrm{d})$ & 24 & 87.50 & 18.02 & & & \\
\hline & İlgisiz (e) & 11 & 71.36 & 10.53 & & & \\
\hline
\end{tabular}

Tablo 8 incelendiğinde, baba-tutum değişkenine göre öğrencileri bilişin bilgisi alt boyutuna ilişkin algıları arasında anlamlı bir fark bulunduğu görülmüştür $(F=2.88, p<.05)$. Bu farklıığın yönünün (aşırı serbest<otoriter) arasında olduğu belirlenmiştir. Ancak baba-tutum değişkenine göre ölçeğin geneli ve bilişin düzenlenmesi alt boyutuna ilişkin algıları arasında anlamlı bir farklılık bulunmadığı belirlenmiş̧ir ( $p>$.05). Biliş üstü beceri düzeylerinin ortalama puanları incelendiğinde ise; otoriter olan babaların diğer tutumlara göre daha yüksek ortalamaya sahip olduğu tespit edilmiştir

Tablo 8. Spor Yapan Ortaöğretim Öğrencilerinin Baba-Tutum Değişkenine Göre Analizi

\begin{tabular}{|c|c|c|c|c|c|c|c|}
\hline & Baba-Tutum & $\mathbf{N}$ & $x^{-}$ & Ss & $\mathbf{F}$ & $\mathbf{P}$ & $\begin{array}{l}\text { Anlamlı } \\
\text { Fark }\end{array}$ \\
\hline \multirow{5}{*}{ Bilişin Bilgisi } & Aşırı Serbest (a) & 18 & 39.33 & 10.88 & \multirow{5}{*}{2.88} & \multirow{5}{*}{.02} & \multirow{5}{*}{$a<d$} \\
\hline & Normal (b) & 134 & 46.11 & 9.42 & & & \\
\hline & Aşırı Koruyucu (c) & 68 & 45.51 & 10.33 & & & \\
\hline & Otoriter (d) & 27 & 48.96 & 9.50 & & & \\
\hline & İlgisiz (e) & 12 & 43.66 & 8.33 & & & \\
\hline \multirow{5}{*}{$\begin{array}{l}\text { Bilişin } \\
\text { Düzenlenmesi }\end{array}$} & Aşırı Serbest (a) & 18 & 31.16 & 9.17 & \multirow{5}{*}{1.36} & \multirow{5}{*}{.25} & \\
\hline & Normal (b) & 134 & 34.73 & 8.29 & & & \\
\hline & Aşırı Koruyucu (c) & 68 & 35.64 & 7.94 & & & \\
\hline & Otoriter $(d)$ & 27 & 36.40 & 7.39 & & & \\
\hline & İlgisiz (e) & 12 & 34.16 & 7.43 & & & \\
\hline \multirow{5}{*}{ Ölçeğin Toplamı } & Aşırı Serbest (a) & 18 & 70.50 & 19.45 & \multirow{5}{*}{2.20} & \multirow{5}{*}{.07} & \\
\hline & Normal (b) & 134 & 80.85 & 16.91 & & & \\
\hline & Aşırı Koruyucu (c) & 68 & 81.16 & 17.46 & & & \\
\hline & Otoriter $(d)$ & 27 & 85.37 & 16.21 & & & \\
\hline & İlgisiz (e) & 12 & 77.83 & 15.31 & & & \\
\hline
\end{tabular}


Tablo 9 incelendiğinde, fiziksel dinçlik düzeyi değişkenine göre öğrencilerin bilişüstü becerilerine ve bilişin bilgisi alt boyutuna ilişkin algıları arasında anlamlı farklılı olmadığı gözlemlenmiştir ( $p>05$ ). Fiziksel dinçlik düzeyi değişkeni ile öğrencilerin bilişin düzenlenmesi alt boyutuna ilişkin algıları arasında istatistiksel olarak anlamlı farklılık görülmüştür $(F=2.41, \quad p<.05)$.Fakat ortalama puanlar incelendiğinde biliş üstü beceri düzeylerinin fiziksel dinçlik düzeyleri zayıf olanların daha yüksek ortalamaya sahip oldukları görülmüştür.

Tablo 9. Spor Yapan Ortaöğretim Öğrencilerinin Fiziksel Dinçlik Düzey Değişkenine Göre Analizi

\begin{tabular}{|c|c|c|c|c|c|c|}
\hline & $\begin{array}{c}\text { Fiziksel Dinçlik } \\
\text { Düzeyi }\end{array}$ & $\mathbf{N}$ & $x^{-}$ & Ss & $\mathbf{F}$ & $\mathbf{P}$ \\
\hline \multirow{5}{*}{ Bilişin Bilgisi } & Çok iyi (a) & 76 & 46.81 & 12.22 & \multirow{5}{*}{1.41} & \multirow{5}{*}{.23} \\
\hline & İyi (b) & 89 & 46.29 & 8.48 & & \\
\hline & Orta (c) & 70 & 43.94 & 9.19 & & \\
\hline & Zayıf (d) & 11 & 47.81 & 8.70 & & \\
\hline & Çok Zayıf (e) & 13 & 42.23 & 6.59 & & \\
\hline \multirow{5}{*}{$\begin{array}{l}\text { Bilişin } \\
\text { Düzenlenmesi }\end{array}$} & Çok iyi (a) & 76 & 36.77 & 9.37 & \multirow{5}{*}{2.41} & \multirow{5}{*}{.05} \\
\hline & İyi (b) & 89 & 34.58 & 7.51 & & \\
\hline & Orta (c) & 70 & 33.20 & 7.56 & & \\
\hline & Zayıf (d) & 11 & 37.54 & 9.26 & & \\
\hline & Çok Zayıf (e) & 13 & 32.53 & 4.31 & & \\
\hline \multirow{5}{*}{ Ölçeğin Toplamı } & Çok iyi (a) & 76 & 83.59 & 20.87 & \multirow{5}{*}{1.88} & \multirow{5}{*}{.11} \\
\hline & İyi (b) & 89 & 80.87 & 15.16 & & \\
\hline & Orta (c) & 70 & 77.14 & 15.98 & & \\
\hline & Zayıf (d) & 11 & 85.36 & 16.91 & & \\
\hline & Çok Zayıf (e) & 13 & 74.76 & 10.19 & & \\
\hline
\end{tabular}

Tablo 10 incelendiğinde, psikolojik dinçlik düzeyi değişkenine göre öğrencilerin bilişüstü becerilerine ve ölçeğin alt boyutlarına ilişkin algıları arasında anlamlı fark olmadığı bulunmuştur. Fakat ortalama puanlar incelendiğinde üst bilişsel beceri düzeylerinin psikolojik dinçlik düzeyleri çok iyi olanların daha yüksek ortalamaya sahip oldukları görülmüştür.

Tablo 10. Spor yapan ortaöğretim öğrencilerinin psikolojik dinçlik düzey değişkenine göre Analizi

\begin{tabular}{|c|c|c|c|c|c|c|}
\hline & $\begin{array}{c}\text { Psikolojik Dinçlik } \\
\text { Düzeyi }\end{array}$ & $\mathbf{N}$ & $x^{-}$ & Ss & $\mathbf{F}$ & $\mathbf{P}$ \\
\hline \multirow{5}{*}{ Bilişin Bilgisi } & Çok iyi & 58 & 46.77 & 11.32 & \multirow{5}{*}{.75} & \multirow{5}{*}{.56} \\
\hline & İyi & 95 & 46.23 & 9.38 & & \\
\hline & Orta & 66 & 44.43 & 9.47 & & \\
\hline & Zayıf & 16 & 43.25 & 8.79 & & \\
\hline & Çok Zayıf & 24 & 45.79 & 10.03 & & \\
\hline \multirow{5}{*}{$\begin{array}{l}\text { Bilişin } \\
\text { Düzenlenmesi }\end{array}$} & Çok iyi & 58 & 36.25 & 9.30 & \multirow{5}{*}{1.41} & \multirow{5}{*}{.23} \\
\hline & İyi & 95 & 35.60 & 7.89 & & \\
\hline & Orta & 66 & 33.54 & 7.79 & & \\
\hline & Zayıf & 16 & 33.06 & 6.47 & & \\
\hline & Çok Zayıf & 24 & 33.54 & 7.98 & & \\
\hline \multirow{5}{*}{ Ölçeğin Toplamı } & Çok iyi & 58 & 83.03 & 19.98 & \multirow{5}{*}{1.07} & \multirow{5}{*}{.37} \\
\hline & İyi & 95 & 81.83 & 16.22 & & \\
\hline & Orta & 66 & 77.98 & 16.46 & & \\
\hline & Zayıf & 16 & 76.31 & 14.93 & & \\
\hline & Çok Zayıf & 24 & 79.33 & 17.62 & & \\
\hline
\end{tabular}


Tablo 11 incelendiğinde, sağlıklı beslenme değişkenine göre öğrencilerin bilişin bilgisi alt boyutu ilişkin algıları arasında anlamlı fark olduğu belirlenmiştir $(F=3.20, p<.05)$. Buna karşılık sağlıklı beslenme değişkenine göre biliş üstü becerilerine ve bilişin düzenlenmesi alt boyutuna yönelik algıları arasında anlamlı fark bulunmadığı tespit edilmiştir (p>.05). Ancak ortalama puanlar incelendiğinde sağlıklı beslenenlerin daha yüksek ortalama puana sahip olduğu görülmüştür.

Tablo 11. Spor Yapan Ortaöğretim Öğrencilerinin Sağlıklı Beslenme Değișkenine Göre Analizi

\begin{tabular}{llccccc}
\hline \multicolumn{2}{c}{$\begin{array}{c}\text { Sağlıklı } \\
\text { Beslenme }\end{array}$} & $\mathbf{N}$ & $\mathbf{X}^{-}$ & Ss & $\mathbf{F}$ & $\mathbf{P}$ \\
\hline \multirow{3}{*}{ Bilişin Bilgisi } & Evet & 121 & 47.23 & 10.57 & & \\
& Hayır & 52 & 43.44 & 8.46 & 3.20 & .04 \\
& Kısmen & 86 & 44.82 & 9.39 & & \\
\hline \multirow{2}{*}{ Bilişin } & Evet & 121 & 35.89 & 8.83 & & .16 \\
Düzenlenmesi & Hayır & 52 & 33.61 & 6.93 & 1.86 & \\
& Kısmen & 86 & 34.20 & 7.78 & & .06 \\
\hline \multirow{3}{*}{ Ölçeğin Toplamı } & Evet & 121 & 83.12 & 18.51 & & \\
& Hayır & 52 & 77.05 & 14.77 & 2.78 & \\
& Kısmen & 86 & 79.03 & 16.45 & & \\
\hline
\end{tabular}

\section{Tartışma ve Sonuç}

Bu çalışmada ortaöğretimin altıncı yedinci ve sekizinci sınıflarında öğrenim gören ve farklı branşlardaspor yapan 150 kadın 109 erkek, toplam 259 öğrencinin üst bilişsel beceri düzeylerinin tespiti ve çeşitli değişkenler yönünden incelenmesi amaçlanmıştır.

Spor yapan öğrencilerin üstbiliş becerilerine ilişkin algıları ile cinsiyet arasında anlamlı farklılı olmadığı ancak kadınların üstbiliş beceri düzeylerinin az farkla erkeklerden yüksek olduğu görülmüştür. Solmaz (2015) üniversitede öğrenim gören bireylerin farklı değişkenler ile üstbilişsel okuma stratejilerini incelenmiş ve çalışmanın sonucunda ise üstbiliş okuma stratejilerini kullanma düzeylerinin öğrencilerin cinsiyetlerine göre farklı olmadığını gözlemlemiştir. Farklı bir çalışmada ise Sarpkaya ve arkadaşları (2011) öğretmen adaylarının üstbiliş stratejilerini kullanma farkındalıkları incelemiş ve çalışmanın sonucunda cinsiyete göre anlamlı farklılaşma olmadığını ortalamalar incelendiğinde ise kadınların erkeklere göre üst-biliş düzeylerinin daha yüksek olduğu saptanmışır. Bağçeci, Döş, Sarıca (2011) iseilköğretim öğrencilerinin üstbilişsel farkındalıklarını incelediği araştırmanın sonucunda kızların üstbilişsel farkındalık düzeylerinin erkeklere göre daha yüksek ve daha başarılı olduğunu tespit etmiştir.Bu çalışmaların sonucu yapmış olduğumuz çalışmanın sonucu ile benzerlik göstermektedir.Bu benzerliğin sebebi yaş ve okul seviyelerinin aynı olmasından kaynaklanmaktadır. Aydın ve Yerdelen (2015) ise lise seviyesindeki öğrencilerin biyoloji dersinde yararlandıkları üstbiliş stratejilerini incelemiş ve sonuç olarak cinsiyet değişkeninin üstbiliş strateji kullanımını istatistiksel açıdan anlamlı bir biçimde yordamakta olduğu sonucuna varmışlardır. Illköğretim ve ortaöğretim öğrencileri üzerinde yapılan araştırmalarda öğrencilerin üstbilişsel farkındalıklarının cinsiyete göre farklılaştığı belirlenmiştir (Bozkurt \& Memiş, 2013; Karatay, 2010; Koç \& Karabağ, 2013; Öztürk \& Kurtuluş, 2017). Bu çalışmaların sonuçları ise çalışmamızın sonucunu destekler nitelikte değildir.

Öğrencilerin bilişüstü becerilerine ilişkin algıları aile yaş arasında anlamlı farklıık bulunmadığı ancak ölçeğin bilişin bilgisi alt boyutunda 12 yaşındaki öğrencilerde, bilişin düzenlenmesi alt boyutunda ise 13 yaşındaki öğrencilerde diğer yaş grubuna göre daha yüksek olduğu bulgulanmıştır. Genelde çocuklarda üstbiliş yaş ilerledikçe gelişir ve bu gelişme aynı zamanda zihinsel davranışta yaşa bağlı gelişimle de ilintilidir (Schneider ve Lockl, 2002; Çakıroğlu, 2007). Kana (2014) çalışmasında ise 
ortaokul öğrencilerinin okuma stratejileri bilişüstü farkındalık düzeylerini belirlemek ve öğrencilerin üstbiliş okuma strateji kullanım düzeyleriyle çeşitli değişkenler arasındaki ilişkiyi tespit etmek amacıyla yaptığı çalışma sonucunda yaş değişkeni arasında anlamlı ilişkiler bulunmuştur. Tuncer ve Kaysi (2013) ise öğretmen adaylarında üst biliş düşünme becerilerinin değerlendirilmesini amaçladığı çalışmalarında yaş değişkeni yönünden yapılan karşılaştırmalarda alternatif değerlendirme becerisi alt faktöründe anlamlı düzeyde fark bulunmuştur. Bu iki çalışmanın sonucu bu araştırmanın sonucu ile benzerlik göstermektedir.

Öğrencilerin bilişüstü becerilerine ilişkin algıları ile sınıf değişkeni arasında anlamlı farklıık bulunmadığı ortalama puanlar incelendiğinde ise biliş üstü beceri düzeylerinin 7. sınıftaki öğrencilerin diğer sınıflara göre daha yüksek olduğu bulgulanmıştır. Ataalkın (2012) 5. sınıf öğrenciler üzerinde yaptığı çalışmada öğrencilerin üst bilişsel farkındalıklarını, biliş üstü becerilerini incelemiş ve sonucunda istatistiksel yönden anlamlı farklılıklar bulunduğu tespit etmiştir. Bu iki çalışmanın sonucu çalışmamızın sonucuyla benzerlik göstermektedir. Memiş ve Arıcan (2013) yaptıkları farklı bir çalışmada 5. sınıftaki öğrencilerin matematiksel üstbiliş düzeylerini incelemiş ve sonucunda beşinci sınıf öğrencilerinin bilişüstü bilgi ve becerilerinin yeterli seviyede bulunduğu görülmüştür.

Öğrencilerin üst bilişsel becerilerine ilişkin algıları ve spor türü değişkenleri arasında anlamlı farklıı̆ın bulunmadığı tespit edilmiştir. Bununla birlikte bilişin bilgisi alt boyutunda bireysel spor yapan katılımcıların üst bilişsel beceri düzeylerinin yüksek olduğu görülürken; bilişin düzenlenmesi alt boyutunda ise takım sporu yapan katılımcıların üst bilişsel beceri düzeylerinin yüksek olduğu görülmüştür. Ahn ve Fedewa, (2011) yapmış oldukları meta-analiz çalışmasında, çocukların zihinsel sağlığı üzerinde fiziksel aktivitenin etkilerinin anlamlı olduğunu belirtmişlerdir. Theodosiou, Mantis ve Papaioannou, (2008) 510 öğrenci üzerinde yapmış oldukları çalışmada, beden eğitimi derslerinde üstbilişsel aktivite, hedef yönelimi ve algılanan motivasyonel iklimi araştırmışlardır. Öğrencilerin kişisel yetenekleri ve gelişimlerine yönelik motivasyonel iklimin oluşturulmasının, üstbilişsel farkındalık yolunda da gelişim sağlayabileceğini belirtmişlerdir.

Spor yapan öğrencilerin üstbiliş düzeylerine ilişkin algıları ile sağlıklı beslenme değişkeni arasında yapılan karşılaştırmada ölçeğin bilişin bilgisi alt boyutunda anlamlı bir farklılık bulunduğu görülmüştür. Ayrıca ölçeğin bütünü incelendiğinde sağlıklı beslenenlerin üst-biliş beceri düzeylerinin daha yüksek olduğu görülmüştür. Bilişsel gelişim ile yetersiz beslenme ve özellikle iyot, demir, çinko, B vitaminleri, çoklu doymamış yağ asitleri gibi bazı besin maddelerinin yetersiz alımı ile ilişkili olmasının yanı sıra düşük doğum ağırlığı ve daha sonraki dönemlerde de kahvaltı alışkanlığı önemli rol oynamaktadır. Öğrencilerin üstbiliş düzeylerine ilişkin algıları ile fiziksel dinçlik düzeyi değişkeni arasında yapılan karşılaştırmada ölçeğin bilişin düzenlenmesi alt boyutunda istatistiksel açıdan anlamlı fark olduğu belirlenmiştir. Ölçek bütün olarak incelendiğinde ise zayıf fiziksel dinçlik düzeyine sahip olan katılımcıların daha yüksek üstbiliş düzeyine sahip oldukları saptanmıştır. Öğrencilerin üst bilişsel beceri düzeylerine ilişkin algıları ile psikolojik dinçlik düzeyi değişkeni arasında yapılan karşılaştırmada ise psikolojik dinçlik düzeyleri çok iyi olanların daha yüksek ortalama puana sahip oldukları saptanmıştır. Öğrencilerin bilişin bilgisi ve bilişin düzenlenmesi alt boyutları ve anne-tutum değişkenleri arasında otoriter olan annelerin lehine istatistiksel olarak anlamlı fark bulunduğu görülürken, bilişin bilgisi alt boyutu ve baba-tutum değişkeni arasında otoriter baba tutumlarının lehine istatistiksel açıdan anlamlı bir farklıık bulunduğu görülmüştür. Bilişin düzenlenmesi alt boyutunun ortalama puanlarına göre ise otoriter olan babaların diğer tutumlara göre daha yüksek puana sahip olduğu görülmüştür. Yapılan literatür taraması sonucunda bu bulguları destekler nitelikte çalışmaya rastlanmadığı gözlemlenmiştir. Bu açıdan bulgulardan elde edilen sonuçlar literatüre katkı sağlaması açısından önem arz etmektedir.

Sonuç olarak; araştırmaya katılan ortaöğretim öğrencilerinin üstbiliş beceri seviyelerinin orta düzeyin üzerinde bulunduğu belirlenmiştir. Araştırmadan elde edilen bu bulguya göre öğrencilerin üstbiliş seviyesinin yeterli seviyede olduğu söylenebilir. Akademik başarı alanında yapılan araştırmalar 
sonucunda öğrencilerin üstbilişsel bilgi ve becerilerinin yeterli düzeyde bulunduğu görülmüştür (Memiş \& Arıcan, 2013; Özsoy, Memiş \& Temur, 2009).

Alanyazınında yapılan araştırmaların genelde akademik başarı ve zeka alanlarında yapııldığı,spor yapan bireyler üzerinde üst bilişsel beceri çalışmalarının yetersiz olduğu görülüp bu tür çalışmaların bir sonraki çalışmalarda daha geniş evrene sahip olarak yapılması, hangi spor branşlarında üst-biliş düzeyin daha yüksek olduğunun belirlenmesi açısından farklı spor branşları arasında karşılaştırma da uygulanması, profesyonel kulüplerde çalışmalar yapılması sporda üstbilişin değerlendirilmesi açısından alana katkıda bulunacağı düşünülmektedir.

\section{Kaynakça}

Akbabaoğlu, M., \& Duban, N. (2020). Sınıf öğretmeni adaylarının üstbilişsel okuma stratejileri, okuma motivasyonları ve kitap okuma alışkanlığına ilişkin tutumları. Uluslararası Türkçe Edebiyat Kültür Eğitim Dergisi, 9(4), 1720-1740. http://dx.doi.org/10.7884/teke.4846

Ataalkın, A.N. (2012). Üst bilişsel öğretim stratejilerine dayalı öğretimin öğrencilerin üst bilişsel farkındalık ve becerisine, akademik başarı ile tutumuna etkisi. Yayımlanmamış Yüksek Lisans Tezi, Akdeniz Üniversitesi, Sosyal Bilimler Enstitüsü, Antalya.

Aydın, A. (1999). Gelişim ve öğrenme psikolojisi. Ankara: Anı Yayıncılık.

Aydın, S. \& Yerdelen, S. (2015). Lise öğrencilerinin biyoloji dersinde kullandıkları üstbiliş stratejilerinin başarı hedef yönelimleri ve öz-yeterlik algıları ile ilişkisinin incelenmesi. Mersin Üniversitesi Eğitim Fakültesi Dergisi, 11(3), 781-792. http://dx.doi.org/10.17860/efd.15845

Bağçeci, B., Döş, B., \& Sarıca, R. (2011). Illköğretim öğrencilerinin üstbilişsel farkındalık düzeyleri ile akademik başarısı arasındaki ilişkinin incelenmesi. Mustafa Kemal Üniversitesi Sosyal Bilimler Enstitüsü Dergisi, 8(16), 551-556.

Baltacı, M. (2009). Web tabanlı excel öğretiminin öğrencilerin akademik başarısı ve bilişötesi farkındalık düzeyine etkisi. Yayımlanmamış Yüksek Lisans Tezi, Fırat Üniversitesi Sosyal Bilimler Enstitüsü, Elazığ.

Baltacı, M. \& Akpınar, B. (2011). Web tabanlı öğretimin öğrenenlerin üstbiliş farkındalık düzeyine etkisi. Mustafa Kemal Üniversitesi Sosyal Bilimler Enstitüsü Dergisi, 8(16), 319-333.

Brown, A. (1987). Metacognition, executive control, self regulation, and other mysterious mechanisms. F.E. Weinert ve R. H. Kluwe, (Ed.), Metacognition, motivation, and understanding (65-116). Hillsdale New Jersey: Lawrence Erlbaum Associates.

Büyüköztürk, Ş. (2017). Sosyal bilimler için veri analizi el kitabi istatistik, araştırma deseni SPSS uygulamaları ve yorum [Data Analysis Handbook for Social Sciences Statistics, Research Pattern SPSS Applications and Interpretation]. Ankara: Pegem Akademi Yayınları. https://doi.org/10.14527/9789756802748

Büyüköztürk, Ş., Çakmak, E. K., Akgün, Ö. E., Karadeniz, Ş. \& Demirel, F. (2012). Bilimsel araştırma yöntemleri. Ankara: Pegem Akademi.

Crick, F. (2000) Şaşırtan varsayım (Çev. Sabit Say). Ankara: TÜBiTAK.

Çakıroğlu, A. (2007). Üstbiliş. Türkiye Sosyal Araştırmalar Dergisi, 11(2), 21-27. 
Çınar O., Teyfur E., \& Teyfur M., (2006). Illköğretim okulu öğretmen ve yöneticilerinin yapılandırmacı eğitim yaklaşımı ve programı hakkındaki görüşleri. Inönü Üniversitesi Eğitim Fakültesi Dergisi, 7(11), 47-64.

Dean, D. \& Kuhn, D. (2003). Metacognition and critical thinking. Educational Resources Information Center (ER/C), 1-11.

Desoete, A. \& Ozsoy, G. (2009). Metacognition, more than the lognes monster?. International Electronic Journal of Elementary Education, 2(1), 1-6.

Desoete, A., \& Roeyers, H. (2002). Off-line metacognition - A domain-specific retardation in young children with learning disabilities. Learning Disability Quarterly. 25, 123-139. https://doi.org/10.2307/1511279

Dienes Z, \& Perner J (1999) A theory of implicit and explicit knowledge. Cambridge: Cambridge University Press.

Doğan E. (2009). Meslek liselerinde çalışan öğretmenlerin üstbiliş becerileri ile sosyal uyumları arasındaki ilişki (Istanbul Anadolu yakası örneği). Yayımlanmamış Yüksek Lisans Tezi, Yeditepe Üniversitesi, Sosyal Bilimler Enstitüsü, İstanbul.

Doğan, A. (2013). Üstbiliş ve üstbilişe dayalı ögretim. Middle Eastern ve Africa Journal of Educational Research.Special Issue of Student Research congress on Educational Sciences, 3, 6-20.

Erdamar Koç G. (2007). Beyin temelli öğrenme, eğitimde yeni yönelimler. Özcan Demirel (Edt.), Eğitimde Yeni Yönelimler (s. 111-121). Ankara: Pegem Yayıncılık.

Esmer, E. ve Yorulmaz, A. (2017). Üst bilişsel farkındalık ölçeği öğretmen formunun geçerlilik ve güvenirlik analizi.Bartın Üniversitesi Eğitim Fakültesi Dergisi, 6(3), 955-966. https://doi.org/10.14686/buefad.306102

Flavell, J. H. (1987) Speculation about the nature and development of metacognition. F. Weinert \&R. Kluwe, (Ed.), Metacognition, motivation, and understanding (21-29). Hillsdale, NJ: Lawrence Erlbaum.

Gama, C. A. (2004). Integrating metacognition instruction in interactive learning environments (Unpublished doctoral dissertation). University of Sussex, Brighton.

George, D., \& Mallery, M. (2010). SPSS for Windows Step by Step: A Simple Guide and Reference, 17.0 update (10a ed.). Boston: Pearson.

Hacker, D.J. \& Dunlosky, J. (2003). Not all metacognition is created equal. New Directions For Teaching And Learning, 95, 73-79. https://doi.org/10.1002/tl.116

Hanten, G., Dennis, M., Zhang, L., Barnes, M., Roberson, G., Archibald, J., Song, J., \& Levin, S. H. (2004). Childhood head injury and metacognitive processes in language and memory. Developmental Neuropsychology, 25(1-2), 85-106. https://doi.org/10.1080/87565641.2004.9651923

Huitt, W. (1997). Metacognition. educational psychology Interactive. Valdosta, GA: Valdosta State University.

Kana, F. (2014) Ortaokul öğrencilerinin üstbiliş okuma stratejileri farkındalık düzeyleri. Erzincan Üniversitesi Eğitim Fakültesi Dergisi 16(1), 100-120. https://doi.org/10.17556/jef.73171

Karasar, N. (2012). Bilimsel araştırma yöntemi. Ankara: Nobel Yayın Dağıtım.

Karasar, N. (2016). Bilimsel araştırma yöntemi. Ankara: Nobel Yayınları. 
Kiremitçi, O., \& Canpolat A. M. (2014). Beden eğitimi ve spor yüksekokulu öğrencilerinin çoklu zekâ alanlarının üstbilişsel farkındalık ve problem çözme becerilerini belirlemedeki rolü. Hacettepe Journal of Sport Sciences, 25 (3), 118-126.

Kuhn, D., \& Dean Jr., D. (2004). Metacognition: A bridge between cognitive psychology and educational practice. Theory into Practice, 43(4), 268-273. https://doi.org/10.1207/s15430421tip4304_4

Martinez, M.E. (2006). What is metacognition?. The Phi Delta Kappan, 87(9), 696-699.

McCormick, C. B. (2003). Metacognition and learning. In W. M. Reynolds; G. E. Miller; I. B. Weiner (Eds.) Handbook of Psychology, 7 (79-102). USA: John Willey and Sons, Inc.

Memiş, A. \& Arıcan, H. (2013). Beşinci sınıf öğrencilerinin matematiksel üstbiliş düzeylerinin cinsiyet ve başarı değişkenleri açısından incelenmesi. Karaelmas Journal of Educational Sciences, 1(1), 76-93.

Metcalfe J. \& Shimamura A. P. (1996). Metacognition: Knowing about knowing. Cambridge Mass: MIT Press.

Nelson, T. O. \& Narens, L. (1996). Why Investigate metacognition? J. Metcalfe ve A. P. Shimamura, (Ed.), Metacognition (1-25). USA: MIT Press.

Oğuz, A., \& Kutlu-Kalender, M. D. (2018). Ortaokul öğrencilerinin üstbilişsel farkındalıkları ile öz yeterlik algıları arasındaki ilişki. Eğitimde Kuram ve Uygulama, 14(2), 170-186. https://doi.org/10.17244/eku.319267

Özbay, M. \& Bahar, M.A. (2012). İleri okur ve üstbiliş eğitimi. Uluslararası Türkçe Edebiyat Kültür Eğitim Dergisi,1(1), 58-177.

Özkaya, Ö.M. (2017). The role of metacognitive skills in predicting achievement motivation, Bartın Üniversitesi Eğitim Fakültesi Dergisi, 6(3), 1040 - 1055. https://doi.org/10.14686/buefad.336767

Özsoy, G. (2008). Üstbiliş. Türk Eğitim Bilimleri Dergisi, 6(4), 713-740.

Özsoy, G., Memiş, A. \& Temur, T. (2009). Metacognition, study habits and attitudes. International Electronic Journal of Elementary Education, 2(1), 154-166.

Pintrich, P.R., Smith, D.A., Garcia, T. \& McKeachie, W.J. (1991). A manual for the use of the motivated strategies for learning questionnaire (MSLQ). Ann Arbor, MI: National Center for Research to improve Postsecondary Teaching and Learning.

Pressley, M., \& Harris, K.R. (2012). Cognitive strategies instruction: from basic research to classroom instruction. Alexander, P.A and Winne, P.H. (Ed). Handbook of Educational Psychology. NY: Taylor and Francis.

Saban, A. (2009). Öğrenme Öğretme Süreci. Yeni Teori ve Yaklaşımlar (5. Baskı). Ankara: Nobel Yayıncılık.

Sarpkaya, G., Arık, G., \& Kaplan, H.A. (2011). Ilköğretim matematik öğretmen adaylarının üstbiliş stratejilerini kullanma farkındalıkları ile matematiğe karşı tutumları arasındaki ilişki. Sosyal Bilimler Araştırmaları Dergisi, 2, 107-122.

Schneider, W. \& K. Lockl (2002). The development of metacognitive knowledge in children and adolescents.In: T. Perfect, B. Schwartz (eds.). Applied metacognition. West Nyack, NY, USA: Cambridge University Press.

Schraw, G. (1998). Promoting general metacognitive awareness. Instructional Science. 26, 113-125.

Selçuk, Z. (1997) Eğitim Psikolojisi. Ankara: Pegem Yayınevi. 
Şahan, H., Akpınar S., Ulukan, M., \& Akpınar, Ö. (2008). The role of communication technology in the relation of sports and media. Niğde University Journal of Physical and Sports Sciences, 2(2), 155-163.

Theodosiou, A., Mantis K., \& Papaioannou, A. (2008). Student self-reports of metacognitive activity in physical education classes. age-group differences and the effect of goal orientations and perceived motivational climate. Educational Research and Review, 3(12), 353-364.

Tosun, A., \& Irak, M. (2008). Üstbiliş ölçeği-30' un türkçe uyarlaması, geçerliği, güvenirliği, kaygı ve obsesif-kompulsif belirtilerle ilişkisi. Türk Psikiyatri Dergisi, 19(1), 67-80.

Tuncer, M., \& Kaysi, F. (2013). Öğretmen adaylarının üst biliş düşünme becerileri açısından değerlendirilmesi. Turkish Journal of Education, 2(4), 44-54. https://doi.org/10.19128/turje.181069

Tuncer, M., \& Kaysi, F. (2013). The development of the metacognitive thinking skills scale. International Journal of Learning \& Development, 3(2), 70-76. https://doi.org/10.5296/ijld.v3i2.3449

Tuzcuoğlu, S., \& Özcan, G. (2014). Lisanslı Olarak Spor Yapan Ve Spor Yapmayan Ortaokul Öğrencilerinin Üst Bilişsel Farkındalık Düzeyleri, Uluslararası Avrasya Sosyal Bilimler Dergisi, 5 (16), 158-175.

Yalız-Solmaz, Y.D. (2015). The metacognitive reading strategies of students: A research school of physical education and sports at Anadolu University. Pamukkale Journal of Sport Sciences, 6(1), 25-38.

Yetim, A. A. (2000). Sosyoloji ve Spor. Ankara: Topkar Matbaacılık.

Yıldız, E., Akpınar, E., Tatar, N., \& Ergin, Ö. (2009). Ilköğretim öğrencileri için geliştirilen bilişüstü ölçeğinin açımlayıcı ve doğrulayıcı faktör analizi. Kuram Ve Uygulamada Eğitim Bilimleri, 9(3), 1573-1604.

Yıldız, E., \& Ergin, Ö. (2007). Bilişüstü ve fen öğretimi. Gazi Üniversitesi Eğitim Fakültesi Dergisi, 27(3), $175-196$.

Bu çalışma, 4-6 Haziran 2020 tarihleri arasında düzenlenen 3. Uluslararası Sağlık Bilimleri ve Yaşam Kongresi'nde çevrimiçi sözel bildiri olarak sunulmuştur 